\title{
4. ASPECTS OF CALCAREOUS NANNOFOSSIL BIOSTRATIGRAPHY AND ABUNDANCE IN THE PLIOCENE AND LATE MIOCENE OF SITE $905^{1}$
}

\author{
S. Gartner ${ }^{2}$ and J.-P. Shyu ${ }^{2}$
}

\begin{abstract}
Continental rise Site 905 yielded upper Miocene and Pliocene uniform hemipelagic mud (a contourite) from approximately 215 to 540 meters below seafloor. The nannofossil biostratigraphy of this interval was reexamined using closely spaced samples from core interiors. Additionally, total nannofossil abundances and dominant species and species group abundances were determined to evaluate the potential of this section for extracting sequence stratigraphic information. The data indicate that the putative hiatuses at the end of the late Pliocene (Zones NN17 and NN18) and in the early Pliocene (Zones NN13 and NN14) probably are condensed intervals, but the base of the late Miocene is almost certainly marked by an unconformity. Judging from carbonate content and sedimentation rate both, nannofossil abundance may be governed by carbonate dissolution or by siliciclastic dilution. Consequently, condensed sections cannot be identified by the abundance of pelagic component in the sediment alone, as is possible in equivalent age Gulf of Mexico sediments. Where nannofossil preservation is adequate in consecutive samples, as in the early Pliocene and latest late Miocene, total nannofossil abundance fluctuates regularly and with a periodicity of less than $10^{5} \mathrm{yr}$, which suggests that dilution of the pelagic component occurred with a frequency probably related to astronomical forcing.
\end{abstract}

\section{INTRODUCTION}

Site 905 is located on the upper continental rise off the New Jersey coast in $2698 \mathrm{~m}$ of water, well seaward of other sites drilled during Leg 150. Among the objectives of this site was to "provide improved chronology of the ... marker horizons (reflectors) ... [and] to evaluate the causal relationship between deep water changes, glaciation, and sea level history" (p. 257, Mountain, Miller, Blum, et al., 1994). Sites $902,903,904$, and 906 bear an overwhelming imprint of continental slope processes, as do the slightly more basinward holes drilled at Sites 604 and 605 (Deep Sea Drilling Project Leg 93) and Sites 612 and 613 (DSDP Leg 95). Site 603 (DSDP Leg 93) is well beyond the slope on the distal part of the rise where the influence of slope processes is masked altogether by the influence of abyssal circulation (van Hinte, Wise, et al., 1987). Site 905 would be that happy location where the influence of sea-level changes (expressed as the distal edge of mass-wasting deposits) and of deep circulation and boundary currents can all be discerned.

The section recovered at Site 905 includes an expanded interval of Pliocene and upper Miocene sediments, sandwiched between two unconformities, and extending from about 218 meters below seafloor (mbsf) to about $580 \mathrm{mbsf}$. The sediments in this interval consist of fairly uniform hemipelagic mud in which calcareous nannofossils may be common to abundant and generally in a good state of preservation, although at some levels much or all carbonate has been dissolved and, hence, nannofossils are lacking. (For a lithologic description and preliminary biostratigraphic interpretation of this site, see Mountain, Miller, Blum, et al., 1994). A detailed study of the late Miocene and Pliocene interval was undertaken because it seemed to present an excellent opportunity to test whether the regional sequence

'Mountain, G.S., Miller, K.G., Blum, P., Poag, C.W., and Twichell, D.C. (Eds.), 1996. Proc. ODP, Sci. Results, 150: College Station, TX (Ocean Drilling Program).

2Department of Oceanography, Texas A\&M University, College Station, TX 77843-3146, U.S.A. gartner@astra.tamu.edu stratigraphic framework constructed for this interval by various investigators in the northern Gulf of Mexico area (e.g., Shaffer, 1990; Armentrout and Clement, 1990; Jiang and Watkins, 1992; Jiang, 1993; J.-P. Shyu, unpubl. data) could be applied to the sediments of the Atlantic continental margin, or alternatively, whether the techniques that work well in the Gulf of Mexico slope and rise sediments could be applied on the western North Atlantic margin.

Sequence stratigraphic interpretation of Neogene sediments of the northern Gulf of Mexico involves identification of seismic sequences on geophysical records. The next requirement is construction of a detailed time framework in strategically placed well sections, based mainly on planktonic foraminifer and calcareous nannofossil biostratigraphy. The final part is to determine the proportion of pelagic biogenic particles, mainly coccoliths, present in the sediment. A relatively large proportion of pelagic biogenic particles is associated with rising sea level or transgressive system tract (TST) and sediment starvation, and represents condensed intervals. A diminished pelagic input is interpreted to represent dilution (sometimes overwhelming dilution of pelagic sedimentation) that occurs when siliciclastic sedimentation dominates as sea level dropped or was at a low stand, that is, a lowstand system tract (LST) or shelf margin system tract (SMST). Based on its position and distance from the shelf margin, Site 905 would be expected to favor preservation of the pelagic record of biogenic sedimentation, without being overwhelmed by siliciclastic sedimentation.

The general setting of Site 905 , and the acoustic character of the sediments, indicate that the interval of interest in this study is part of a feature called the Chesapeake Drift. These drift sediments were deposited from contour-following density current of North Atlantic Deep Water (Northern Component Water). Much of the very fine siliciclastic sediment probably was injected into this deep circulation up-current from the depositional site by gravity flows and turbidity currents, eroding and flowing down the continental slope in submarine canyons (see "Background and Objectives" in Mountain, Miller, Blum, et al., 1994, p. 257). Although the above mechanism implies widespread redeposition, here, as in other drift sediments, contami- 
nation of calcareous nannofossils by penecontemporaneous redeposition appears to be minimal. The contaminants that do occur in the coccolith assemblages at this location are generally significantly older-Cretaceous and Eocene-and, hence, readily identified.

\section{MATERIALS AND METHODS}

Samples for this study were taken at $150-\mathrm{cm}$ intervals. One sample per core section was thought adequate in this high sedimentation rate regime. From these samples, slides were prepared without prior processing of the samples. Documentation from these slides is presented in checklist form on Figure 1. Initial sample spacing was arranged to check and refine the preliminary shipboard biostratigraphy. Subsequent examination was made in closely spaced samples in the vicinity of changes in the assemblage to discover the precise ranges of important biomarkers, especially where it was desirable to fill gaps that were previously found to be largely barren of nannofossils.

The shipboard biostratigraphy, which was determined almost entirely from core catcher sample, was checked against the biostratigraphy derived from samples taken from core interiors. For the most part, the two are in reasonably good agreement. At some levels the two were found to be significantly at variance, in which case reliance was placed on the second determination because core catcher samples are likely to be more susceptible to contamination during coring and handling than are the interior parts of cores.

Nannofossil species abundances are recorded semiquantitatively. The abundance categories can be thought of as a geometric progression, each representing approximately a five-fold greater abundance than the next lower category (except for "very rare," for which the next lower category is "not present"). Also recorded is nannofossil abundance in the sample. This determination was made by counting all coccolith and other nannofossil species encountered in 40 random microscope fields viewed at a magnification of 1950x. These semiquantitative techniques for determining relative abundances are less time consuming than actually counting all species, although they are sufficiently accurate for our purpose and also entirely reproducible. The results of this semiquantitative assessment are also given on Figure 1 .

\section{BIOSTRATIGRAPHY}

Examination of the calcareous nannofossils from the interior of the cores led to several small but significant revisions of the shipboard biostratigraphy given in the Initial Reports volume, starting at the top of the interval of interest. Samples 150-905A-26H-1, 71-72 $\mathrm{cm}(215.71 \mathrm{mbsf})$, and $26 \mathrm{H}-2,76-77 \mathrm{~cm}(217.26 \mathrm{mbsf})$, are barren of calcareous nannofossils, but the next lower sample, $26 \mathrm{H}-3,16-18$ $\mathrm{cm}$ (218.16 mbsf), yielded an assemblage in which Discoaster brouweri is the only representative of the genus. This sample is thus assigned to upper Pliocene Zone NN18. Shipboard data obtained from core catcher samples suggests that Zone NN18 was not present, but our data suggest otherwise.

The next lower samples, 150-905A-27X-1, 73-74 cm $(219.73$ mbsf), yielded Discoaster pentaradiatus, a marker for upper Pliocene Zone NN17, but the sample immediately below that, 27X-2, 74-75 $\mathrm{cm}$ (221.24 mbsf), again is barren of nannofossils. Both of the two zones are represented by a very short stratigraphic interval and, thus, are good candidates for condensed sections. However, nannofossils are not particularly abundant, which may be explained by dissolution, a possibility that is compatible with the corroded aspect of some of the nannofossils at this level.

Discoaster surculus occurs from Sample 150-907A-27X-3, 75$76 \mathrm{~cm}$ (222.75 mbsf) downward, indicating the upper part of late Pliocene Zone NN16, and Discoaster tamalis occurs from Sample
150-907A-30X-2, 89-90 cm (244.39 mbsf), indicating the lower part of Zone NN16, thus rounding out the conventionally used upper Pliocene nannofossil biozonal succession. Intervals barren of calcareous nannofossils also occur within Zone NN16 (i.e., at 224.76, $230.77-240.74,248.89,255.60-260.10$, and $268.19 \mathrm{mbsf}$ ), but these barren intervals may distort to some extent the ranges of important late Pliocene biomarkers.

The early Pliocene to late Pliocene transition is marked by the highest occurrence of Reticulofenestra pseudoumbilicus in Sample 150-905A-33X-2, 90-91 cm (273.40 mbsf), and immediately below the highest occurrence of Sphenolithus abies in Sample 150-907A$33 \mathrm{X}-1,89-90 \mathrm{~cm}$ (271.89 mbsf). This transition marks the top of nannofossil Zone NN15. Within the limits of sample spacing, this datum corresponds to the shipboard determination. From this level downward, the early Pliocene is rather more difficult to subdivide because the zonal markers are generally sparse even in the more favorable lithologies of pelagic sediments and more so in this section.

The next lower marker is the highest occurrence of weakly birefringent or nonbirefringent ceratoliths, in this case the species Amaurolithus delicatus, in Sample 150-905A-34X-1, 90-91 cm (281.50 mbsf), and this datum marks the top of Zone NN14. (The problem of which of the three early Pliocene species of Amaurolithus to use as the marker is irrelevant because only Amaurolithus delicatus was recorded this high in this section, and thus it is the determining marker. Moreover, when the zone limit was originally defined (Gartner, 1969), no distinction was made between the three species; that is, all were included in Ceratolithus tricorniculatus.) The next lower biohorizon, which would mark the NN14/NN13 zonal boundary, is the lowest occurrence of Discoaster asymmetricus. This species is unreliable at this site, owing to its very sparse occurrence; consequently, Zones NN14 and NN13 cannot be separately identified. Also some of the section representing these two zones is barren of nannofossils.

The next lower biomarker encountered is the highest occurrence of Ceratolithus armatus in Sample 150-905A-36X-1, 91-92 cm (303.51 mbsf), which is within Zone NN12. The lower limit of nannofossil Zone NN13 at this site must be above this level. Ceratolithus armatus is exceedingly rare, but the closely related species and primary biomarker for the zone, Ceratolithus acutus, occurs just a short distance down in Samples 150-905A-36X-3, 91-92 cm (303.51 mbsf), and 37X-1, 91-92 cm (309.81 mbsf). Although the upper and lower limits of the occurrence of these two species at Site 905 may be somewhat uncertain, a minimum of $15.09 \mathrm{~m}$ of section is assignable to Zones NN13 and NN14. This finding is at variance with shipboard results, which have been interpreted to show a significant hiatus, with the interval represented by Zones NN13 and NN14 missing.

The lower limit of the occurrence of Ceratolithus acutus in Sample $150-905 \mathrm{~A}-37 \mathrm{X}-1,91-92 \mathrm{~cm}$ (309.81 mbsf), is the next lower biohorizon documented, and this datum is within Zone NN12. In particularly favorable pelagic sections, this datum is very close to the highest occurrence of Triquetrorhabdulus rugosus. At Hole 905A, however, the latter species is recorded upward only to Sample 150905A-38X-4, 91-93 cm (323.71 mbsf). Both species are extremely rare here and neither can be assumed a reliable indicator of the biohorizon ideally marked by both, which is more or less the midpoint of Zone NN12. As a compromise solution, the biohorizon could be placed midway between the limits of occurrence of the two, but that would introduce a false impression of accuracy. The correct level of this biohorizon is somewhat important because it is the one nearest to the base of the Pliocene at the stratotype in Sicily (Cita and Gartner, 1973). Unfortunately it cannot be resolved satisfactorily at this site.

The next datum below this is the highest occurrence of Discoaster quinqueramus in Sample 150-905A-39X-1, 90-91 cm (328.60 mbsf). Although rare redeposited specimens are encountered sporadically well above this level, the determination of this biohorizon is quite robust based on the abundance and consistent occurrence of the marker species. This biohorizon, which marks the top of Zone NN11, 


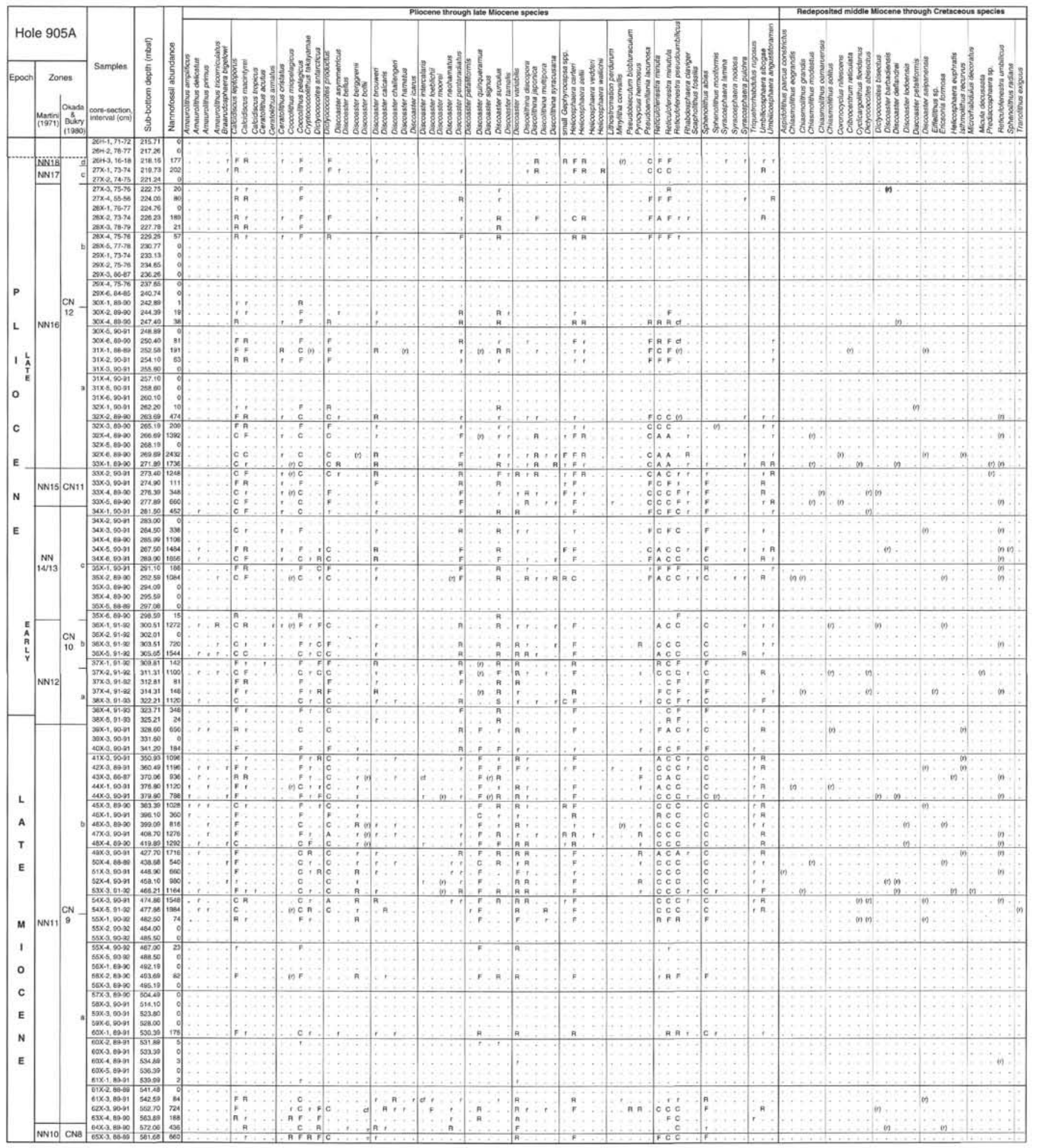

Figure 1. Checklist of calcareous nannofossils for Hole 905A, Core 150-905A-26H through $65 \mathrm{X}$. Symbols for relative abundance: . = not present; $\mathrm{r}=\mathrm{very}$ rare, $\mathrm{R}=\operatorname{rare}, \mathrm{F}=$ few, $\mathrm{C}=$ common, $\mathrm{A}=$ abundant, $\mathrm{W}=$ very abundant, and $(\mathrm{O})=$ redeposited. Nannofossil abundance is the number of specimens in 40 random fields of view at a magnification of $\times 1950$. 
has in the past often arbitrarily been taken to mark the Miocene/ Pliocene boundary, mainly because it is easy to identify in nearly all pelagic and even marginal hemipelagic sediments. Unfortunately, the precise timing of the extinction of the species relative to reestablishment of open marine conditions in the Mediterranean has not yet been documented satisfactorily. It is clear, however, that the inundation that ended the Messinian desiccation of the Mediterranean postdates the extinction of Discoaster quinqueramus, since the oldest postMessinian sediments deposited in the Mediterranean basin lack this species (Cita and Gartner, 1973; Rio et al., 1975; Ellis and Lohman, 1979; Müller, 1978, 1990; Rio et al., 1990).

The upper Miocene section at Hole 905A presents something of a challenge for zonal determination because some of the late Miocene marker species are naturally quite rare, and this is further exacerbated at this site by the intermittently unfavorable lithology and poor preservation state of the nannofossils. Nevertheless, the succession is remarkably close to what may be considered an ideal succession. A short distance below the highest occurrence of Discoaster quinqueramus is the highest occurrence of the closely related but distinctive Discoaster berggrenii in Sample 150-905A-40X-3, 90-91 cm (341.20 mbsf). The species occurs downward to Sample 150-905A$56 \mathrm{X}-2,89-90 \mathrm{~cm}$ (493.69 mbsf), where its range ends in an interval largely barren of nannofossils. Within the upper part of the range of Discoaster berggrenii is contained the range of Amaurolithus amplificus, which extends from Sample 150-905A-44X-1, 90-91 cm (376.80 mbsf), to Sample 46X-1, 90-91 cm (396.10 mbsf). Farther down but still within the range of Discoaster berggrenii is the lower limit of the occurrence of Amaurolithus primus and Amaurolithus delicatus. Thus, in spite of the very rare occurrences of the marker species, the succession clearly is complete to this point. All of the above are within Zone NN11. (For a recent compilation of the succession of Neogene nannofossil biohorizons, see, for example, Young et al., 1994).

The remaining biohorizons of interest in the section are the highest occurrence of Discoaster loeblichii in Sample 150-905A-61X-3, $89-91 \mathrm{~cm}(542.59 \mathrm{mbsf})$, immediately below an interval that is largely barren of calcareous nannofossils, although in parts this interval contains abundant biogenic silica. This same species also occurs in the next lower sample, $150-905 \mathrm{~A}-62 \mathrm{X}-3,90-91 \mathrm{~cm}$ (552.70 mbsf), but not below it. However, Discoaster quinqueramus is still present immediately below in Sample 150-905A-63X-4, 89-90 cm (563.89 mbsf), marking the downward extent of Zone NN11, but below that only very rare Discoaster bellus were found in Sample 150-905A$64 X-3,89-90 \mathrm{~cm}$ (572.06 mbsf). That same sample and the next lower sample, $150-905 \mathrm{~A}-65 \mathrm{X}-3,88-89 \mathrm{~cm}$ (581.66 mbsf), yielded Discoaster bollii, which indicates that these samples should be assigned to the lower part of Zone NN10. The samples at this level are too far apart, however, to clearly confirm or contraindicate a hiatus within the upper part of Zone NN1O.

\section{SEDIMENTATION RATES}

The ages of the various biohorizons have been tabulated (Table 1) using the most recent chronology of Berggren et al. (1995), with some minor additions or corrections where that seems appropriate. That chronology is used for constructing the age-depth (sedimentation rate) plot in Figure 2. (Note that in discussing sedimentation rates the section is treated from the bottom up to preserve the proper time perspective, whereas biostratigraphy is presented from the top down as is done normally.)

The interval immediately above the highest occurrence of Discoaster bollii to the lowest occurrence of Discoaster quinqueramus has a low sedimentation rate $(1.03 \mathrm{~cm} / \mathrm{k} . \mathrm{y}$.) and may, indeed, be marked by a hiatus or multiple hiatuses. A somewhat higher sedimentation rate $(3.14 \mathrm{~cm} / \mathrm{k} . \mathrm{y}$. $)$ characterizes the interval from the lowest occurrence of Discoaster quinqueramus to the highest occurrence of Minylitha convallis. This interval is relatively sandy and its upper part is identified with Reflector Merlin.

The highest sedimentation rate $(29.69 \mathrm{~cm} / \mathrm{k} . \mathrm{y}$. $)$ is in the interval from the highest occurrence of Minylitha convallis to the lowest occurrence of Amaurolithus delicatus. This interval is notably sparsely fossiliferous and also has a relatively low carbonate content. Some carbonate, including coccoliths, may have been removed by dissolution; however, the high sedimentation rate and expanded section point to dilution of pelagic carbonate by siliciclastics as a significant probable cause of reduced carbonate content. Which factor dominated, dissolution of dilution, is unclear, although clearly dissolution was incomplete.

A lesser but still high sedimentation rate $(10.72 \mathrm{~cm} / \mathrm{k} . \mathrm{y}$.$) contin-$ ues from the lowest occurrence of Amaurolithus delicatus to the highest occurrence of Discoaster quinqueramus, the last being very close to, and just below, the Miocene/Pliocene boundary. Immediately above the highest occurrence of Discoaster quinqueramus, and spanning the Miocene/Pliocene boundary, is a sharp decrease in sedimentation rate $(0.74 \mathrm{~cm} / \mathrm{k} . \mathrm{y}$.) to the highest occurrence of Triquetrorhabdulus rugosus, but the sedimentation rate increases again sharply between the last datum and the lowest occurrence of Ceratolithus acutus. Both of the last two biomarkers are very rare in these sediments, and the limit of the range of one or both may be truncated, which would account for the substantial stratigraphic separation of the two $(13.90 \mathrm{~m})$, although they differ in age by only about $0.1 \mathrm{~m} . \mathrm{y}$. (The age estimates of Backman et al. [1990] place them within 50 k.y. of each other, and these ages would dictate an even sharper increase in sedimentation rate for this very short time span. However, according to our compilation the age estimates of Backman et al. [1990] seem to be in error.)

From the lowest occurrence of Ceratolithus acutus to the highest occurrence of Amaurolithus spp. sedimentation rate is a modest 3.75 $\mathrm{cm} / \mathrm{k} . \mathrm{y}$, but drops again sharply from there to the highest occurrence of Reticulofenestra pseudoumbilicus, and beyond to the highest occurrence of Sphenolithus abies. The slight difference between the two should not be over interpreted since it is probably an artefact of sample spacing.

Upper Pliocene sedimentation rates continue to be moderate (3.44 $\mathrm{cm} / \mathrm{k} . \mathrm{y}$.) from the highest occurrence of Sphenolithus abies to the highest occurrence of Discoaster tamalis, and a more robust 10.31 $\mathrm{cm} / \mathrm{k} . \mathrm{y}$. from there to the highest occurrence of Discoaster surculus. An intermediate value of $5.03 \mathrm{~cm} / \mathrm{k} . \mathrm{y}$. is calculated from the Discoaster surculus highest occurrence to the highest occurrence of Discoaster pentaradiatus.

It should be emphasized that the large fluctuations in sedimentation rate still represent an averaging of numbers. They are of interest primarily because the record appears to be continuous, at least within the limits of biostratigraphic resolution.

\section{NANNOFOSSIL ABUNDANCES}

Abundances of nannofossils were determined in several categories: all species of Discoaster combined, Coccolithus pelagicus, the large species Reticulofenestra pseudoumbilicus, all small species of Reticulofenestra combined, and total nannofossil abundance. These abundances are plotted on Figure 3 along with carbonate content and the revised biostratigraphy. As outlined above, the abundance of all species combined should reflect dilution of the pelagic input by nonbiogenic sediments, given that Site 905 has had much the same depositional setting over the time interval represented by the section examined here. Coccolithus pelagicus and the two categories of reticulofenestrid coccoliths (i.e., Reticulofenestra pseudoumbilicus and all small species of Reticulofenestra) were counted because they consistently constitute a significant proportion of the assemblage over this 
Table 1. Nannofossil biohorizons and their depth of occurrence in Hole 905A.

\begin{tabular}{|c|c|c|c|c|}
\hline Datum & $\begin{array}{l}\text { Depth } \\
\text { (mbsf) }\end{array}$ & $\begin{array}{l}\text { Age } \\
\text { (Ma) }\end{array}$ & $\begin{array}{c}\text { Sediment } \\
\text { accumulation rate } \\
(\mathrm{cm} / \mathrm{k} . \mathrm{y} .)\end{array}$ & Sources of age \\
\hline HO Discoaster pentaradiatus & 219.73 & $2.51 *$ & & Backman and Pestiaux (1987); Berggren et al. (1995) \\
\hline HO Discoaster surculus & 222.75 & 2.57 ** & & Backman and Pestiaux (1987); Berggren et al. (1995) \\
\hline HO Discoaster tamalis & 244.39 & 2.78 & $\begin{array}{r}10.31 \\
3.44\end{array}$ & Backman and Pestiaux (1987); Berggren et al. (1995) \\
\hline HO Sphenoliths abies & 271.89 & 3.58 & \multirow{2}{*}{0.90} & Backman and Shackleton (1983); Cande and Kent (1995) \\
\hline HO Reticulofenestra pseudoumbilicus & 273.40 & 3.75 & & Backman and Shackleton (1983); Cande and Kent (1995) \\
\hline LO Pseudoemiliania lacunosa & 292.59 & & \multirow{2}{*}{1.09} & \\
\hline HO Amaurolithus spp. & 281.50 & 4.49 & & Rio et al. (1990); Cande and Kent (1995) \\
\hline HO Ceratolithus acutus & 303.51 & & \multirow{2}{*}{3.57} & \\
\hline LO Ceratolithus acutus & 309.81 & 5.28 & & Cita and Gartner (1973); Hilgen and Langereis (1988) \\
\hline LO Amaurolithus tricorniculatus & 311.31 & & & \\
\hline HO Triquetrorhabdulus rugosus & 323.71 & 5.38 & \multirow{2}{*}{$\begin{array}{r}14.63 \\
0.74\end{array}$} & Backman et al. (1990); Cande and Kent (1995) \\
\hline HO Discoaster quinqueramus & 328.60 & 6.04 & & Hodell et al. (1994); Gartner (1973) \\
\hline HO Discoaster berggrenii & 341.20 & & \multirow{4}{*}{10.72} & \\
\hline HO Amaurolithus amplificus & 376.80 & & & \\
\hline LO Amaurolithus amplificus & 396.10 & & & \\
\hline LO Amaurolithus delicatus & 477.86 & 7.43 & & Young et al. (1994); Cita and Gartner (1973); Cande and Kent (1995) \\
\hline LO Discoaster surculus & 542.59 & & \multirow{2}{*}{29.69} & \\
\hline HO Discoaster loeblichiii & 542.59 & & & \\
\hline HO Minylitha convallis & 542.59 & 7.65 & \multirow{3}{*}{$\begin{array}{l}3.14 \\
1.03\end{array}$} & Gartner (1992); Cande and Kent (1995) \\
\hline LO Discoaster quinqueramus & 563.89 & 8.33 & & Backman et al. (1990); Cande and Kent (1995) \\
\hline HO Discoaster bollii & 572.06 & 9.13 & & Backman et al. (1990); Cande and Kent (1995 \\
\hline
\end{tabular}

Notes: The ages assigned to the biohorizons are compiled from various sources. Bold type indicate biohorizons whose ages we think we know with considerable confidence. $* 2.46-2.56$ and $* * 2.55-2.59$ are both from Berggren et al. (1995).

interval. They also continue through this period of geologic time largely unchanged, except for the precipitous decline and extinction of Reticulofenestra pseudoumbilicus in the mid-Pliocene.

Following previous studies it was reasoned that environmental changes that occurred during deposition of these sediments ought to be reflected by the proportion of the assemblage constituted of these species. Coccolithus pelagicus is well known for its preference for cold water in modern oceans (McIntyre and Bé, 1967), although this species may have had somewhat greater tolerance for warmer ocean climates during earlier parts of its long Cenozoic history. The proportion of large and small species of Reticulofenestra, too, seems to be related to environmental variables, including temperature and very probably productivity (Haq, 1980), and Reticulofenestra pseudoumbilicus is most abundant in deposits from warm and temperate oceans. Discoasters, like Coccolithus pelagicus, are relatively resistant to dissolution, but unlike Coccolithus pelagicus they favor a more temperate ocean climate.

Examination of the abundance plots in Figure 3 indicates that nannofossil abundance appear to be related almost entirely to carbonate content and preservation of the calcareous fossils. Intervals with sparse nannofossils are dominated by residual, solution resistant species, chief among them Coccolithus pelagicus. Thus, neither relative abundances, nor the ratio of the temperate to warm-water species Reticulofenestra pseudoumbilicus to the cold-water species Coccolithus pelagicus, can be used as reliable indicators of environmental change other than intensity of dissolution. This is particularly obvious in a comparison of the above categories with overall abundance of all calcareous nannofossils. The latter tracks carbonate content rather closely when the coccolith abundance curve, which is constructed from a more densely spaced sample set, is smoothed by a 5point moving average (see Fig. 4).

At several levels within the Pliocene and the upper Miocene where nannofossils are sparse, the coccoliths that are present are severely corroded specimens, mainly of solution-resistant species. Those parts of the section where coccoliths are absent have a low carbonate content and, in some cases, are virtually free of carbonate. Significant barren intervals are present in the upper Pliocene from about 230 to 240 mbsf (Cores 150-905A-28X and 29X) and 255 to $260 \mathrm{mbsf}$ (Core 150-905A-31X); in the lower Pliocene from about 293 to 298 mbsf (Core 150-905A-35X); and in the upper Miocene from 483 to 542 mbsf (Cores $150-905 \mathrm{~A}-55 \mathrm{X}$ to $61 \mathrm{X}$ ). Two of these coccolith-barren intervals, the lower Pliocene Core 150-905A-35X and the upper Miocene Core 150-905A-55X, have peak abundances of residual discoasters. A third discoaster abundance peak (in the uppermost Miocene Core 150-905A-38X) also yielded very few nannofossils. However, discoasters seem to be only slightly more resistant to dissolution than most coccoliths, and most coccolith-barren intervals have very few or no discoasters.

The barren intervals are generally unremarkable in that biohorizons are not systematically associated with them (i.e., species' ranges do not terminate at the limits of the barren intervals). It is reasonable to conclude that the barren intervals do not represent significant changes in style of sedimentation but, rather, record changes in bottom-water circulation or in chemistry sufficient to dissolve calcareous fossils. The lowermost barren segment, which is well below the top of the Miocene, differs from the Pliocene barren intervals in that 


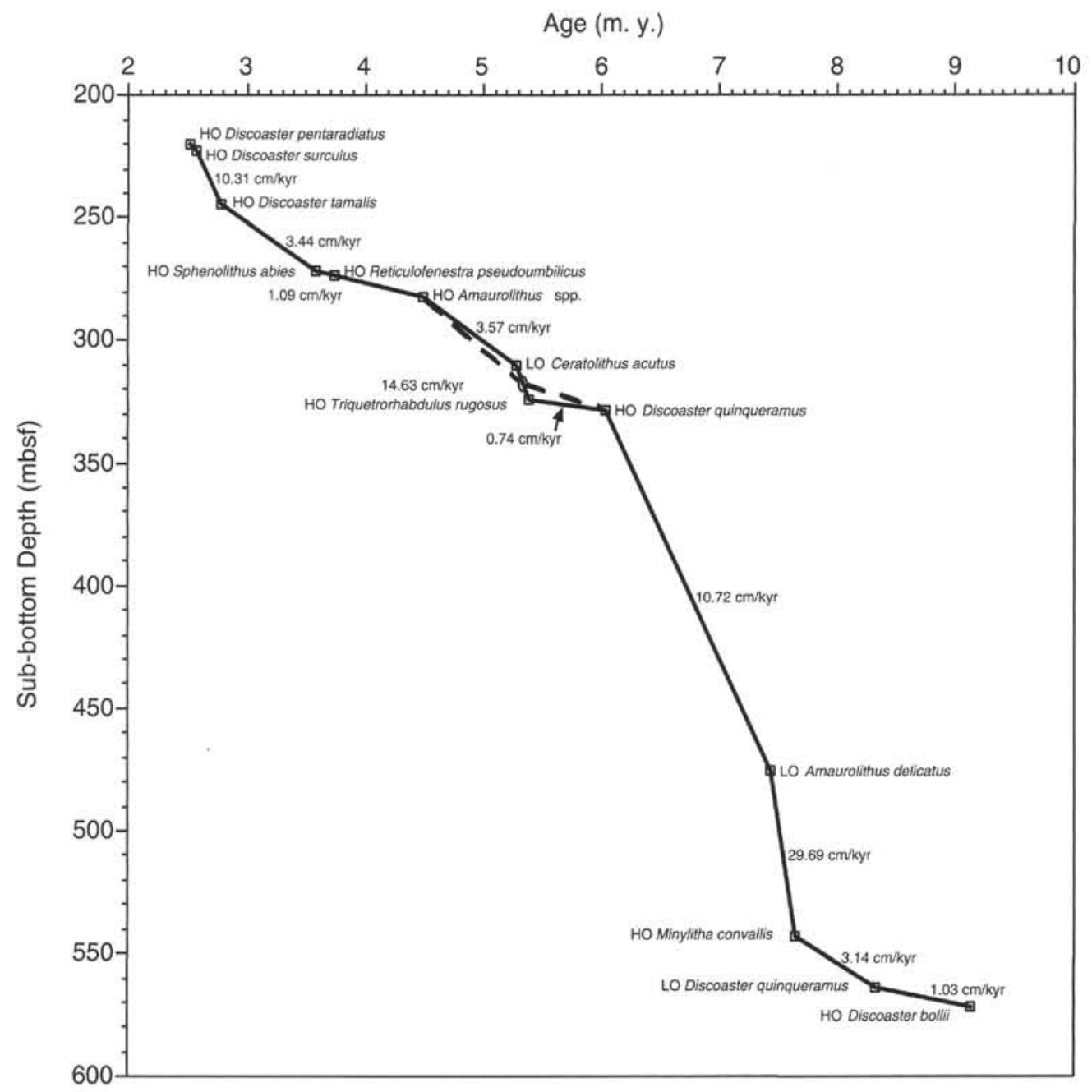

Figure 2. Age-depth plot for the upper Miocene and Pliocene at Hole 905A. The circle is a hypothetical point midway between the highest occurrence of Triquetrorhabdulus rugosus and the lowest occurrence of Ceratolithus acutus. These two biohorizons are normally in close proximity, and either one or both biohorizons may be truncated because both species are extremely sparse.

it contains abundant remains of diatoms and other siliceous microfossils.

It is noted also that none of the barren intervals have a seismic manifestation. None corresponds to a reflector. This, too, may be interpreted to suggest that the causes of dissolution were subtle changes in bottom water chemistry rather than processes associated with continental slope or continental rise sedimentation such as erosion by or deposition from a gravity flow.

\section{UNCONFORMITIES, HIATUSES, AND CONDENSED INTERVALS}

Shipboard examination mainly of core-catcher samples produced a picture of multiple unconformities at this site. Within the interval considered here three unconformities were inferred. One occurred at the top of the Pliocene where the uppermost Pliocene nannofossil Zone (NN18) was thought to be missing. However, closer sample spacing shows that Zone NN18 is present, albeit probably in a condensed or partial form. This interpretation is strengthened by the relatively short interval represented by the next lower Zone NN17, indicating that reduced sedimentation commenced during the time represented by Zone NN17 and continued into Zone NN18.
An unconformity or hiatus was inferred also for the late early Pliocene, where much of nannofossil Zones NN13 and NN14 were thought to be missing. At this level, too, the evidence for an unconformity is equivocal. The biomarker for this interval, Discoaster asymmetricus and species of Amaurolithus, are very rare and occur sporadically in these sediments; hence, zonal assignation can be uncertain except in near ideal sections. Nevertheless, good recovery of nannofossil assemblages in samples from the interior of cores indicates that the section probably is complete within resolution limits of the nannofossil biostratigraphy. However, Zones NN13, NN14, and $\mathrm{NN} 15$ are represented by a relatively short sediment section (low sedimentation rate) as compared with adjacent Zones NN12 (below) and NN16 (above), indicating reduced sedimentation and, hence, probably a condensed section. It has been noted that the reflector associated with this condensed interval (Reflector Blue) has notably low amplitude at this site, unlike reflectors clearly associated with an unconformity or hiatus (Mountain, Miller, Blum, et al., 1994).

The third unconformity inferred for the interval examined here separates the upper Miocene from the middle Miocene. The data indicate that there may indeed be a hiatus between about 572 and 581 mbsf, between the lower part of nannofossil Zone NN11 which extends to the lowest occurrence of Discoaster quinqueramus in Sample $150-905 \mathrm{~A}-63 \mathrm{X}-4,89-90 \mathrm{~cm}$ (563.89 mbsf), and the lower part of 


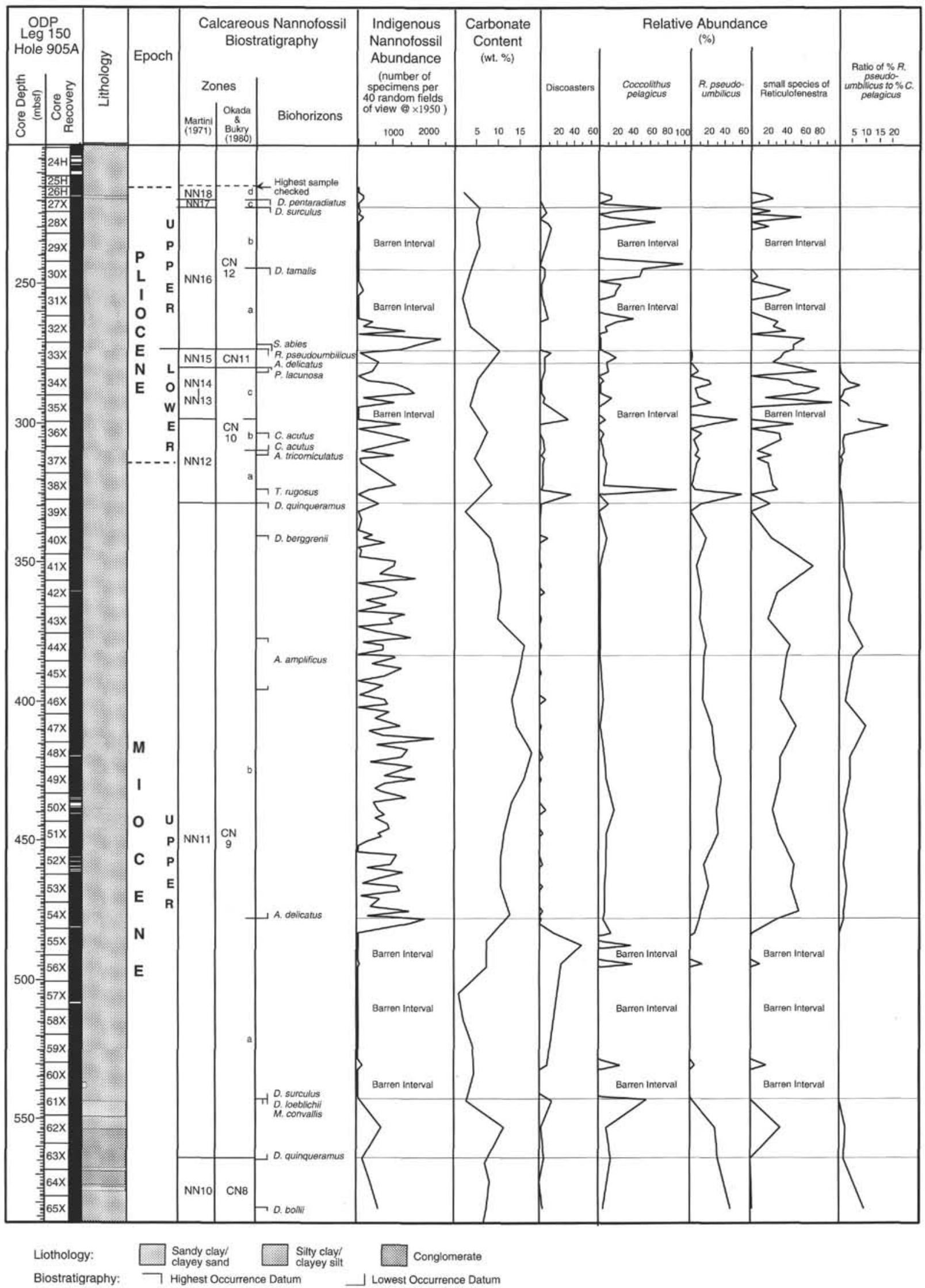

Figure 3. Revised biostratigraphy, total nannofossil abundance, carbonate content, and select species and species group abundances in the late Miocene and Pliocene of Hole 905A. 


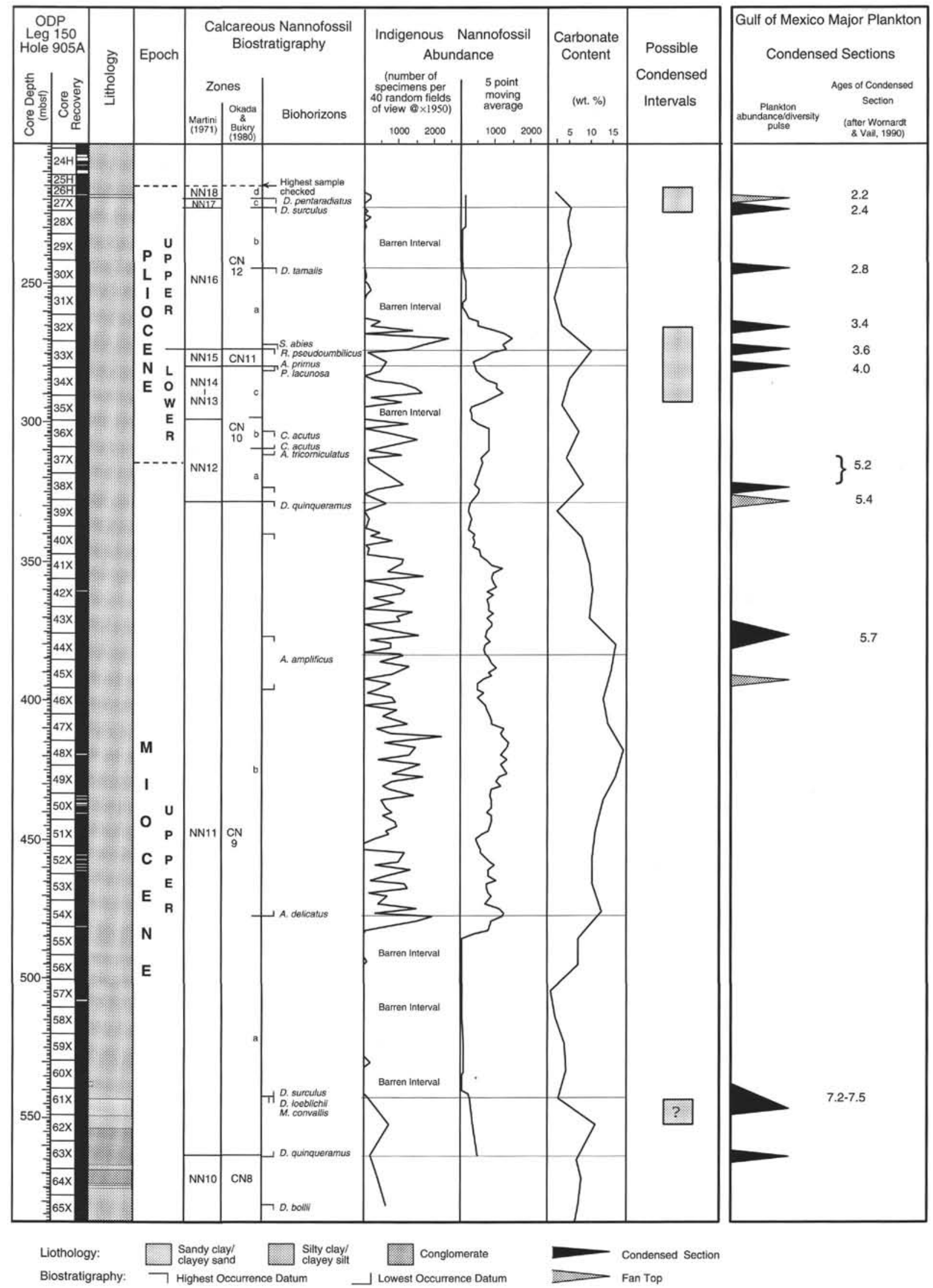

Figure 4. Revised biostratigraphy, total nannofossil abundance, carbonate content, and inferred condensed intervals of Hole 905A. The middle curve is a 5-point moving average of total nannofossil abundances. For reference, prominent condensed intervals in the northern Gulf of Mexico area are given. 
nannofossil Zone NN10, which is marked by the presence of Discoaster bollii in Sample 150-905A-64X-3, 89-90 cm (572.06 mbsf).

The biostratigraphy for Sample 150-905A-63X-4, 89-90 cm, is not in agreement with the lithostratigraphy, in that the sample level is well within the interval of a conglomerate, yet the nannofossil assemblage clearly is more similar to the assemblage from the overlying upper Miocene hemipelagic mud than to the rest of the conglomerate below. Perchance this sample was mislabeled.

\section{NANNOFOSSIL ABUNDANCE FLUCTUATIONS}

As noted earlier, one objective of this study was to determine whether the regional sequence stratigraphy of the northern Gulf of Mexico off-shore as expressed in calcareous nannofossil abundances has a counterpart on the eastern United States continental margin. For reference a recent compilation of condensed interval succession of the Pliocene and late Miocene in the northern Gulf of Mexico (J.-P. Shyu, unpubl. data) is plotted on the right side of Figure 4. It is clear from this plot that there is at best only a partial correlation (if any) between the coccolith abundance-derived condensed intervals in the northern Gulf of Mexico and coccolith abundances in the sediments on the continental rise off New Jersey. Condensed sections (inferred at Site 905 not from nannofossil abundances but from compression of nannofossil zones, i.e. sedimentation rates) do seem to have counterparts in the Gulf of Mexico in the latest Pliocene (nannofossil Zones NN17 and NN18) and in the latest early Pliocene (nannofossil Zones NN13, NN14, and NN15), and possibly in the early late Miocene (lower part of nannofossil Zone NN11). The last of the three is very problematic as it is associated with very low nannofossil abundance and biostratigraphic uncertainty. The success of this approach in the northern Gulf of Mexico notwithstanding, this approach does not recommend itself for larger regional scale application.

Nannofossil abundances may be worth further scrutiny, however, in a context not anticipated initially. Over much of the late Miocene and through the early Pliocene nannofossil abundances fluctuate with very high frequency. In fact, most of the high and low values are single point peaks, which almost certainly means that sample spacing was not sufficiently close to show the true pattern. What is clear is that nannofossil abundances in these hemipelagic muds fluctuate regularly, with relatively high amplitude, and with short period. Counting peaks between two reasonably reliable biohorizons, the highest occurrence of Reticulofenestra pseudoumbilicus at the top (3.75 Ma) and the lowest occurrence of Amaurolithus delicatus at the bottom (7.43 Ma or less) yields at least 36 - possibly 40 - peaks, indicating a periodicity of less than $90 \mathrm{ka}$. Clearly, the data are not sufficient to make claims as to the nature or cause of this periodicity, except to note that closer scrutiny may be in order, and that Milankovitch-type periodicity may be an appropriate signal to look for (e.g., Tiedemann et al., 1994; Hodell et al., 1994). Beyond that it may be useful to establish whether the proximal cause of the periodicity is siliciclastic sediment input by changes of sea level, by fluctuation of intensity of deep circulation, or by removal of carbonate from the sediment by aggressive bottom waters.

\section{ACKNOWLEDGMENT}

The manuscript was reviewed by Luc Beaufort and John Steinmetz. Their efforts are appreciated.

\section{REFERENCES}

Armentrout, J.M., and Clement, J.F., 1990. Biostratigraphic calibration of depositional cycles: a case study in High Island-Galveston-East Breaks areas, offshore Texas. In Armentrout, J.M., and Perkins, B.F. (Eds.), Sequence Stratigraphy as an Exploration tool: Concepts and Practices in the Gulf Coast. GCSSEPM Found. 11th Ann. Res. Conf., Progr. and Abstr., 21-51.

Backman, J., and Pestiaux, P., 1987. Pliocene Discoaster abundance variations, Deep Sea Drilling Project Site 606: biochronology and paleoenvironmental implications. In Ruddiman, W.F., Kidd, R.B., Thomas, E., et al., Init. Repts. DSDP, 94 (Pt. 2): Washington (U.S. Govt. Printing Office), 903-910.

Backman, J., Schneider, D.A., Rio, D., and Okada, H., 1990. Neogene lowlatitude magnetostratigraphy from Site 710 and revised age estimates of Miocene nannofossil datum events. In Duncan, R.A., Backman, J., Peterson, L.C., et al., Proc. ODP, Sci. Results, 115: College Station, TX (Ocean Drilling Program), 271-276.

Backman, J., and Shackleton, N.J., 1983. Quantitative biochronology of Pliocene and early Pleistocene calcareous nannofossils from the Atlantic, Indian and Pacific oceans. Mar. Micropaleontol., 8:141-170.

Berggren, W.A., Hilgen, F.J., Langereis, C.G., Kent, D.V., Obradovich, J.D., Raffi, I., Raymo, M.E, and Shackleton, N.J., 1995. Late Neogene chronology: new perspectives in high-resolution stratigraphy. Geol. Soc. Am. Bull., 107:1272-1287.

Cande, S.C., and Kent, D.V., 1995. Revised calibration of the geomagnetic polarity timescale for the Late Cretaceous and Cenozoic. J. Geophys. Res., 100:6093-6095.

Cita, M.B., and Gartner, S., 1973. The stratotype Zanclean foraminiferal and nannofossil biostratigraphy. Riv. Ital. Paleontol. Stratigr., 79:503-558.

Ellis, C.H., and Lohman, W.H., 1979. Neogene calcareous nannoplankton biostratigraphy in eastern Mediterranean deep-sea sediments. Mar. Micropaleontol., 4:61-84

Gartner, S., 1969. Correlation of Neogene planktonic foraminifer and calcareous nannofossils zones. Trans. Gulf Coast Assoc. Geol. Soc., 19:585599.

, 1973. Absolute chronology of the late Neogene calcareous nannofossil succession in the Equatorial Pacific. Geol. Soc. Am. Bull., 84:2021-2034.

1992. Miocene nannofossil chronology in the North Atlantic, DSDP Site 608. Mar. Micropaleontol., 18:307-331.

Haq, B.U., 1980. Biogeographic history of Miocene calcareous nannoplankton and paleoceanography of the Atlantic Ocean. Micropaleontology, 26:414-443.

Hilgen, F.J., and Langereis, C.G., 1988. The age of the Miocene-Pliocene boundary in the Capo Rossello area (Sicily). Earth Planet. Sci. Lett., 91:214-222.

Hodell, D.A., Benson, R.H., Kent, D.V., Boersma, A., and Rakic-El Bied, K., 1994. Magnetostratigraphic, biostratigraphic, and stable isotope stratigraphy of an Upper Miocene drill core from the Salé Briqueterie (northwestern Morocco): a high-resolution chronology for the Messinian stage. Paleoceanography, 9:835-855.

Jiang, M.M., 1993. Miocene sequence stratigraphy of the northern Gulf of Mexico. Trans. Gulf Coast Assoc. Geol. Soc., 43:137-144.

Jiang, M.M., and Watkins, J.S., 1992. Floral pulses, foraminiferal peaks and inferred sequences in the Miocene of the northern Gulf of Mexico. Mar. Pet. Geol., 9:608-622.

Martini, E., 1971. Standard Tertiary and Quaternary calcareous nannoplankton zonation. In Farinacci, A. (Ed.), Proc. 2nd Int. Conf. Planktonic Microfossils Roma: Rome (Ed. Tecnosci.), 2:739-785.

McIntyre, A., and Bé, A.W.H., 1967. Modern coccolithophoridae of the Atlantic Ocean. I: placoliths and cyrtoliths. Deep-Sea Res. Part A, 14: 561-597.

Mountain, G.S., Miller, K.G., Blum, P., et al., 1994. Proc. ODP, Init. Repts., 150: College Station, TX (Ocean Drilling Program).

Müller, C., 1978. Neogene calcareous nannofossils from the Mediterranean-Leg 42A of the Deep Sea Drilling Project. In Hsü, K.J., Montadert, L., et al., Init. Repts DSDP, 42 (Pt. 1): Washington (U.S. Govt. Printing Office), 727-751.

Müller, C., 1990. Nannoplankton biostratigraphy and paleoenvironmental interpretations from the Tyrrhenian Sea, ODP Leg 107 (Western Mediterranean). In Kastens, K.A., Mascle, J., et al., Proc. ODP, Sci. Results, 107: College Station, TX (Ocean Drilling Program), 495-511.

Okada, H., and Bukry, D., 1980. Supplementary modification and introduction of code numbers to the low-latitude coccolith biostratigraphic zonation (Bukry, 1973; 1975). Mar. Micropaleontol., 5:321-325.

Rio, D., Mazzei, R., and Palmieri, G., 1975. The stratigraphic position of the Mediterranean upper Miocene evaporites, based on nannofossils. Mem. Soc. Geol. Ital., 16:261-276. 
Rio, D., Raffi, I., and Villa, G., 1990. Pliocene-Pleistocene calcareous nannofossil distribution patterns in the Western Mediterranean. In Kastens, K.A., Mascle, J., et al., Proc. ODP, Sci. Results, 107: College Station, TX (Ocean Drilling Program), 513-533.

Shaffer, B.L., 1990. The nature and significance of condensed sections in Gulf Coast late Neogene sequence stratigraphy. Trans. Gulf Coast Assoc. Geol. Soc., 40:767-776.

Tiedemann, R., Sarnthein, M., and Shackleton, N.J., 1994. Astronomic timescale for the Pliocene Atlantic $\delta^{18} \mathrm{O}$ and dust flux records of Ocean Drilling Program Site 659. Paleoceanography, 9:619-638.

van Hinte, J.E., Wise, S.W., Jr., et al., 1987. Init. Repts. DSDP, 93 (Pts. 1 and 2): Washington (U.S. Govt. Printing Office).

Wornardt, W.W., and Vail, P.R., 1990. Revision of the Plio-Pleistocene cycles and their application to sequence stratigraphy of shelf and slope sediments in the Gulf of Mexico. In Armentrout, J.M., and Perkins, B.F. (Eds.), Sequence Stratigraphy as an Exploration Tool: Concepts and Practices in the Gulf Coast. GCSSEPM Found. 11th Ann. Res. Conf., Progr. and Abstr., 391-397.

Young, J.R., Flores, J.-A., Wei, W., Backman, J., Hamrsmid, B., van Heck, S., Krhovsky, J., Raffi, I., di Stefano, A., Villa, G., and Wise, S.W., 1994. A summary chart of Neogene nannofossil magnetobiostratigraphy. $J$. Nannoplankton Res., 16:21-27.

Date of initial receipt: 2 March 1995

Date of acceptance: 26 September 1995

Ms 150SR-039 